ENVIRONMENTAL RESTORATION PROGRAM

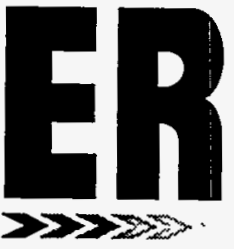




\section{Author Affiliations}

The authors of this report are available to answer questions on the Environmental Restoration (ER) radiological surveys discussed in these pages and to provide further information on the ER Remote Sensing Program. They may be contacted by telephone, mail, or Internet at the following addresses:

Mr. John L. Smyre

423-574-2968

P.O. Box 2008

Oak Ridge National Laboratory

Computational Physics

and Engineering Division

Bldg. 4500-N, MS-6274

Oak Ridge, TN 37831-6274

Internet: smyrejl@.ornl.gov
Mr. Brent W. Moll

423-574-6335

P.O. Box 2008

Oak Ridge National Laboratory

Computational Physics

and Engineering Division

Bldg. 4500-N, MS-6274

Oak Ridge, TN 37831-6274

Internet: mollbw@ornl.gov
Ms. Amy Delf King

423-576-1509

P.O. Box 2008

Oak Ridge National Laboratory

Computational Physics

and Engineering Division

Bldg. 4500-N, MS-6274

Oak Ridge, TN 37831-6274

Internet: kingal@ornl.gov

This report has been reproduced directly from the best available copy.

Available to DOE and DOE contractors from the Office of Scientific and Technical Information, P.O. Box 62, Oak Ridge, TN 37831; prices available from 423-576-8401 (fax 423-576-2865).

Available to the public from the National Technical Information Service, U.S. Department of Commerce, 5285 Port Royal Rd., Springfield, VA 22161. 


\title{
Gamma Radiological Surveys of the Oak Ridge Reservation, Paducah Gaseous Diffusion Plant, and Portsmouth Gaseous Diffusion Plant, 1990-93, and Overview of Data Processing and Analysis by the Environmental Restoration Remote Sensing Program, Fiscal Year 1995
}
J. L. Smyre
B. W. Moll
A. L. King

Date Issued-June 1996

\author{
Prepared by \\ Computational Physics and Engineering \\ Oak Ridge National Laboratory \\ Oak Ridge, TN
}

\section{Prepared for the}

U. S. Department of Energy

Office of Environmental Management

under budget and reporting code EW 20

LOCKHEED MARTIN ENERGY SYSTEMS, INC.

managing the

Environmental Management Activities at the

Oak Ridge K-25 Site Paducah Gaseous Diffusion Plant

Oak Ridge Y-12 Plant Portsmouth Gaseous Diffusion Plant

Oak Ridge National Laboratory

under contract DE-AC05-84OR21400

for the

U.S. DEPARTMENT OF ENERGY 


\section{PREFACE}

This technical report discussing data collection, processing, and analyses conducted by the Remote Sensing Program was prepared as textual documentation for aerial gamma data that were delivered to the Oak Ridge Environmental Information System (OREIS) for inclusion in the OREIS consolidated data system. This work was performed under Work Breakdown Structure 1.4.12.2.3.04.05, Activity Data Sheet 8304, and Milestone Number 8304-08-05, Selected Aerial Gamma Data to OREIS.'

\section{DISCLAIMER}

This report was prepared as an account of work sponsored by an agency of the United States Government. Neither the United States Government nor any agency thereof, nor any of their employees, makes any warranty, express or implied, or assumes any legal liability or responsibility for the accuracy, completeness, or usefulness of any information, apparatus, product, or process disclosed, or represents that its use would not infringe privately owned rights. Reference herein to any specific commercial product, process, or service by trade name, trademark, manufacturer, or otherwise does not necessarily constitute or imply its endorsement, recommendation, or favoring by the United States Government or any agency thereof. The views and opinions of authors expressed herein do not necessarily state or reflect those of the United States Government or any agency thereof.

${ }^{1}$ Reference herein to any specific commerical product, process, or service by trade name, trademark, manufacturer, or otherwise, does not necessarily constitute or imply its endorsement, recommendation or favoring by the Unites States Government or any agency thereof. 



\section{ACKNOWLEDGMENTS}

Credit for the data importation into Arc/Info, data transformations and projection changes, and generation of plots for reference and quality assurance belongs to Brent W. Moll. The writers wish to acknowledge and thank Mark A. Tuttle for the use of Arc/Info Arc Macro Language scripts and plant boundaries used in the analysis of the Paducah and Portsmouth radiological data. We are also grateful to Edward A. Bright for the use of LANDSAT Thematic Mapper imagery for registration and backdrop analysis of the Clinch River gamma survey. 


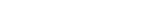




\section{CONTENTS}

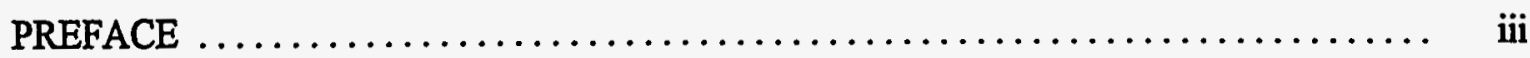

ACKNOWLEDGMENTS $\ldots \ldots \ldots \ldots \ldots \ldots \ldots \ldots \ldots \ldots \ldots \ldots \ldots \ldots \ldots \ldots$

FIGURES $\ldots \ldots \ldots \ldots \ldots \ldots \ldots \ldots \ldots \ldots \ldots \ldots \ldots \ldots \ldots \ldots \ldots \ldots \ldots \ldots \ldots \ldots \ldots$

ABBREVIATIONS $\ldots \ldots \ldots \ldots \ldots \ldots \ldots \ldots \ldots \ldots \ldots \ldots \ldots \ldots \ldots \ldots \ldots \ldots \ldots \ldots \ldots \ldots \ldots$

EXECUTIVE SUMMARY $\ldots \ldots \ldots \ldots \ldots \ldots \ldots \ldots \ldots \ldots \ldots \ldots \ldots \ldots \ldots \ldots \ldots \ldots \ldots \ldots \ldots$

1. INTRODUCTION $\ldots \ldots \ldots \ldots \ldots \ldots \ldots \ldots \ldots \ldots \ldots \ldots \ldots \ldots \ldots \ldots \ldots \ldots \ldots \ldots \ldots \ldots$

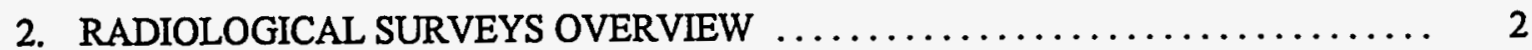

2.1 GENERAL PURPOSE AND METHODOLOGY $\ldots \ldots \ldots \ldots \ldots \ldots \ldots \ldots \ldots, 2$

2.2 PREVIOUS SURVEYS . . . . . . . . . . . . . . . . . .

2.2.1 Paducah Gaseous Diffusion Plant $(1990) \ldots \ldots \ldots \ldots \ldots \ldots \ldots \ldots \ldots$

2.2.2 Portsmouth Gaseous Diffusion Plant (1990) ................. 3

2.2.3 Oak Ridge Reservation (1992) ........................ 4

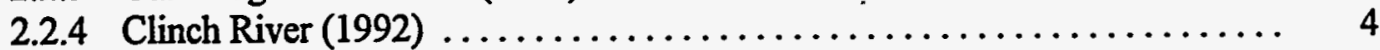

2.2.5 Portsmouth Gaseous Diffusion Plant (1993) ................. 4

3. DATA PROCESSING AND QUALITY ASSURANCE

(GIS AND COMPUTER MODELING, CPED) .................... 6

3.1 PROCESSED DATA DELIVERED BY CONTRACTOR (EG\&G/EM) ........ 6

3.1.1 Paducah Gaseous Diffusion Plant $(1990) \ldots \ldots \ldots \ldots \ldots \ldots \ldots \ldots . \ldots \ldots$

3.1.2 Portsmouth Gaseous Diffusion Plant $(1990) \ldots \ldots \ldots \ldots \ldots \ldots \ldots \ldots$

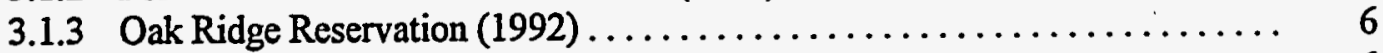

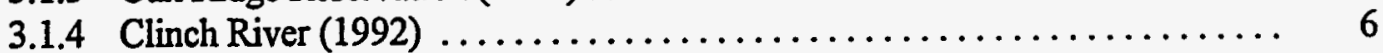

3.1.5 Portsmouth Gaseous Diffusion Plant (1993) ................. 6

3.2 SUMMARY OF DATA TRANSFORMATION AND ANALYSIS

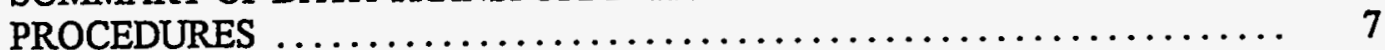

4. DESCRIPTIONS OF GROSS COUNT AND MAN-MADE GAMMA

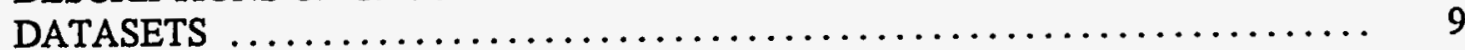

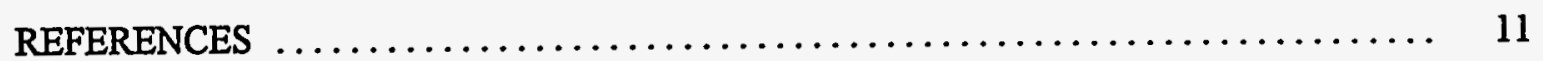

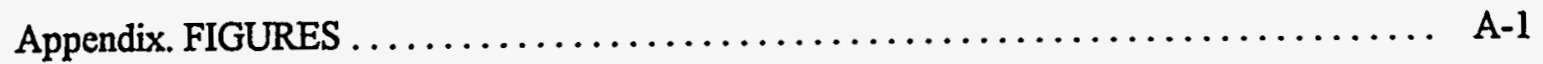





\section{FIGURES}

1. Contours of man-made gamma radiation at Paducah Gaseous Diffusion Plant. . . . . . A A-3

2. Contours of man-made gamma radiation at Portsmouth Gaseous Diffusion Plant (1990). ... A A-5

3. Man-made gamma radiation contours at Oak Ridge Reservation $\ldots \ldots \ldots \ldots \ldots \ldots \ldots$ A-7

4. Man-made gamma radiation contours at Oak Ridge National Laboratory (X-10 Plant) . . . . . A-9

5. Man-made gamma radiation contours at $\mathrm{K}-25$ Plant. $\ldots \ldots \ldots \ldots \ldots \ldots \ldots \ldots \ldots$ A-11

6. Contours of man-made gamma radiation at $\mathrm{Y}-12$ Plant. $\ldots \ldots \ldots \ldots \ldots \ldots \ldots \ldots \ldots$

7. Contours of man-made gamma radiation near East Fork Poplar Creek. . . . . . . . A-15

8. Man-made gamma radiation counts along the Clinch River. $\ldots \ldots \ldots \ldots \ldots \ldots \ldots$ A-17

9. Contours of man-made gamma radiation at Portsmouth Gaseous Diffusion Plant (1993). . . . A-19 


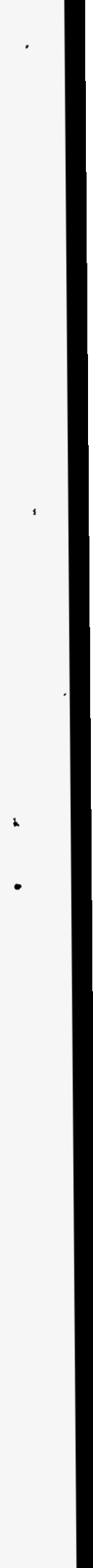




\section{ABBREVIATIONS}

AGL

above ground level

DOE

EG\&G/EM

U.S. Department of Energy

EG\&G Energy Measurements

ER

GCM

GPS

IR

NAD

OREIS

ORNL

Environmental Restoration

GIS and Computer Modeling

Global Positioning System

infrared

North American Datum

Oak Ridge Environmental Information System

Oak Ridge National Laboratory

Oak Ridge Reservation

PGDP

Paducah Gaseous Diffusion Plant

PORTS

REDAR IV

ROI

USRADS

UTM

Portsmouth Gaseous Diffusion Plant

Radiation and Environmental Data Acquisition and Recorder System, Version IV

region of interest

Ultrasonic Ranging and Data Systems

Universal Transverse Mercator 



\section{EXECUTIVE SUMMARY}

Three gamma radiological surveys have been conducted under auspices of the ER Remote Sensing Program: (1) Oak Ridge Reservation (ORR) (1992), (2) Clinch River (1992), and (3) Portsmouth Gaseous Diffusion Plant (PORTS) (1993). In addition, the Remote Sensing Program has acquired the results of earlier surveys at Paducah Gaseous Diffusion Plant (PGDP)(1990) and PORTS (1990). These radiological surveys provide data for characterization and long-term monitoring of U.S. Department of Energy (DOE) contamination areas since many of the radioactive materials processed or handled on the ORR, PGDP, and PORTS are direct gamma radiation emitters or have gamma emitting daughter radionuclides.

High resolution airborne gamma radiation surveys require a helicopter outfitted with one or two detector pods, a computer-based data acquisition system, and an accurate navigational positioning system for relating collected data to ground location. Sensors measure the ground-level gamma energy spectrum in the 38 to $3,026 \mathrm{KeV}$ range. Analysis can provide gamma emission strength in counts per second for either gross or total man-made gamma emissions. Gross count gamma radiation includes natural background radiation from terrestrial sources (radionuclides present in small amounts in the earth's soil and bedrock), from radon gas, and from cosmic rays from outer space as well as radiation from man-made radionuclides. Man-made count gamma data include only the portion of the gross count that can be directly attributed to gamma rays from man-made radionuclides. Interpretation of the gamma energy spectra can make possible the determination of which specific radioisotopes contribute to the observed man-made gamma radiation, either as direct or as indirect (i.e., daughter) gamma energy from specific radionuclides (e.g., cesium-137, cobalt-60, uranium-238). 



\section{INTRODUCTION}

The Environmental Restoration (ER) Remote Sensing and Special Surveys Program was established in 1992 to apply the benefits of remote sensing technologies to Environmental Restoration and Waste Management programs at all of the five U.S. Department of Energy (DOE) facilities operated and managed by Lockheed Martin Energy Systems, Inc.-the three Oak Ridge Reservation (ORR) facilities, the Paducah Gaseous Diffusion Plant (PGDP), the Portsmouth Gaseous Diffusion Plant (PORTS), and adjacent off-site areas. The Remote Sensing Program includes the management of routine and special surveys at these sites, application of state-of-the-art remote sensing and geophysical technologies, and data transformation, integration, and analyses required to make the information valuable to ER. Remotely sensed data include natural color and color infrared (IR) aerial photography, 12-band multispectral scanner imagery, predawn thermal IR sensor imagery, magnetic and electromagnetic geophysical information, and gamma radiological data.

Information derived from the Remote Sensing Program is invaluable for many reasons. It provides data that can be used to locate potential contamination sources and characterize waste sites efficiently; to document land use and waste site activity; to detect and monitor temporal changes associated with contaminant transport and remediation efforts; to establish baselines for comparison with future conditions; to provide a database for detailed analysis, comparisons, and integration with field measurements and map data; and to fuel geographic database improvements (e.g., facility layout, land cover, topography). The worth of these technologies, particularly in a sustained program, can be demonstrated throughout the remediation life cycle.

This report describes in some detail recent gamma radiological surveys of the ORR, PGDP, and PORTS. 


\section{RADIOLOGICAL SURVEYS OVERVIEW}

\subsection{GENERAL PURPOSE AND METHODOLOGY}

Gamma radiological surveys provide data for characterization and long-term monitoring of U.S. Department of Energy (DOE) contamination areas since many of the radioactive materials processed or handled on the Oak Ridge Reservation (ORR), Paducah Gaseous Diffusion Plant (PGDP), and Portsmouth Gaseous Diffusion Plant (PORTS) are direct gamma radiation emitters or have gamma emitting daughter radionuclides. High resolution airborne gamma radiation surveys require a helicopter outfitted with one or two detector pods, a computer-based data acquisition system, and an accurate navigational positioning system for relating collected data to ground location. Greater gamma sensitivity can be obtained with soil at low water content, favoring surveys during the late summer and early autumn from August through October. Sensors measure the ground-level gamma energy spectrum in the 38 to $3,026 \mathrm{KeV}$ range. Analysis can provide gamma emission strength in counts per second for either gross or total man-made gamma emissions. Gross count gamma radiation includes natural background radiation from terrestrial sources (radionuclides present in small amounts in the earth's soil and bedrock), from radon gas, and from cosmic rays from outer space as well as radiation from man-made radionuclides. Man-made count gamma data include only the portion of the gross count that can be directly attributed to gamma rays from man-made radionuclides. Interpretation of the gamma energy spectra can make possible the determination of which specific radioisotopes contribute to the observed man-made gamma radiation, either as direct or as indirect (i.e., daughter) gamma energy from specific radionuclides (e.g., cesium-137, cobalt-60, uranium-238).

\subsection{PREVIOUS SURVEYS}

Four aerial radiological surveys on the ORR were conducted prior to the advent of the Environmental Restoration (ER) Remote Sensing Program by EG\&G Energy Measurements (EG\&G/EM) operating out of the DOE Remote Sensing Laboratory, Las Vegas, Nevada. These previous surveys include:

1. 1973 ORR using fixed-wing aircraft flying at 500 feet altitude above ground level (AGL) at a speed of 170 knots (sites with anomalous radiation levels were re-surveyed using helicopterborne instrumentation at 250 feet AGL);

2. 1980 ORR and surrounding area flying parallel lines 500 feet apart at 300 feet AGL;

3. 1986 White Oak Floodplain, flying parallel flight lines 125 feet apart at 150 feet AGL; and

4. 1989 ORR and surrounding area using parameters identical to the 1980 survey.

These surveys will not be further discussed in this report.

Three radiological surveys have been conducted under auspices of the ER Remote Sensing Program: (1) ORR (1992), (2) Clinch River (1992), and (3) PORTS (1993). In addition, the Remote Sensing Program has acquired the results of earlier surveys at Paducah (1990) and Portsmouth (1990). Each of these surveys was conducted by EG\&G/EM. 
Two related surveys of radiological information have been completed. As a part of the geophysical surveys conducted on the ORR by Geonex Aerodat, Ltd. in January 1993 raw gamma data were collected from a helicopter along north-south (administrative grid) flight lines. The Aerodat survey complements the coverage of the 1992 EG\&G/EM survey to provide data across the entire ORR. An additional ground-based Ultrasonic Ranging and Data Systems (USRADS) walkover survey of the SWSA-4 site by Chemrad Tennessee Corporation (September 14, 1993 to March 4, 1994) collected detailed radiological data in addition to geophysical data. Because these datasets require extensive transformations and interpretation by geophysicists, they are not further discussed in this document.

Each of the five recent EG\&G surveys is briefly described in the following paragraphs.

\subsubsection{Paducah Gaseous Diffusion Plant (1990)}

An aerial gamma survey of the PGDP was conducted May 15-25, 1990, at 200 feet AGL flown at 70 knots (Fig. 1). These parameters were the same as those used in an earlier survey in 1976. The 1990 survey examined 62 square kilometers that included the PGDP and surrounding area and used a flight line spacing of 350 feet. The only man-made radionuclide detected within the facility in both the 1976 and 1990 surveys was protactinium-234, indicative of a uranium-238 source. The same anomalous areas were detected in both surveys.

During the 1990 aerial survey, an in situ survey was conducted May 17-24, 1990. The in situ survey included measurements using a High Purity Germanium detector and ground sampling. Ground samples were analyzed by EG\&G/EM, Santa Barbara, CA, in a laboratory radionuclide assay. Results of the in situ measurements indicated naturally occurring radioisotopes, cesium-137 from international fallout, and some evidence of anomalous uranium-238. Soil sampling showed naturally occurring radioisotopes, cesium-137, and anomalous uranium-238.

\subsubsection{Portsmouth Gaseous Diffusion Plant (1990)}

An aerial radiological survey was conducted from July 11-20, 1990 over the entire Portsmouth plant and vicinity near Piketon, Ohio (Fig. 2). This survey was conducted by a helicopter flying at a speed of 70 knots and an altitude of 300 feet and following a series of parallel flight lines separated by 400 feet. Two detector pods and a lightweight version of the Radiation and Environmental Data Acquisition and Recorder System, Version IV (REDAR IV) were on board the aircraft. An ultrahighfrequency ranging system and a radar altimeter were employed to establish helicopter position. Ground-based soil sample measurements were collected at five locations for validation of aerial data.

Both gross count analysis (counts in the spectrum between 38 and 3,026 KeV) and man-made count extraction were performed. Contours of the terrestrial gamma exposure rate extrapolated to 1 meter AGL were generated on a spatial basis. Terrestrial gamma exposure rates varied from roughly 7 to 14 microroentgens per hour at 1 meter above ground. Analysis of man-made sources and for the U-238 decay product protactinium-234m revealed elevated protactinium readings at five sites within the plant boundary. Uranium-235 was also noted during spectral analysis of data obtained over the processing plant facility. No other sources of man-made gamma-emitting material were detected either on- or off-site. The only major difference from a similar 1984 radiological survey was the presence in the survey area in 1990 of a truck carrying radioactive uranium hexafluoride. 


\subsubsection{Oak Ridge Reservation (1992)}

An aerial radiological survey was conducted from March 30 to April 14, 1992, over 55 square miles at several sites on the ORR (Fig. 3) and surrounding area near Oak Ridge, Tennessee. The survey area included the Oak Ridge National Laboratory (ORNL) (Fig. 4), the K-25 Site (former Gaseous Diffusion) Plant (Fig. 5), the Y-12 Plant (Weapons Production) (Fig. 6), Freels Bend Area/Oak Ridge Associated Universities, East Fork Poplar Creek (100-year floodplain extending from the K-25 Site to the Y-12 Plant)(Fig. 7), Elza Gate (former uranium ore storage site in the city of Oak Ridge), Parcel A, the Clinch River (river banks from Melton Hill Dam to the city of Kingston) (Fig. 8), and the CSX Railroad Tracks (from the Y-12 Plant to the city of Oak Ridge).

This survey was conducted at an altitude of 150 feet along a series of parallel east-west flight lines 250 feet apart flown at a speed of 70 knots. Helicopter-borne instrumentation included two large detector pods and a REDAR IV. A Global Positioning System (GPS) differential navigation system allowed georeferencing of recorded data. Ground-based soil samples and exposure rates were collected at seven locations for validation of aerial data.

Both gross count analysis (counts in the spectrum between 38 and $3,026 \mathrm{keV}$ ) and man-made count extraction were performed. Gamma energy spectra from survey regions exhibiting man-made radioactivity were further analyzed for isotopic identification, with photopeak rates being determined for cesium-137 and cobalt-60. Contours of the terrestrial gamma exposure rate extrapolated to 1 meter AGL were generated on a spatial basis. Terrestrial gamma exposure rates varied from roughly 7 to 11 microroentgens per hour at 1 meter above ground. Analysis revealed man-made radionuclides, cobalt-60 and cesium-137, and man-concentrated radionuclides, uranium-235 and uranium-238, at several facilities on the ORR and surrounding area.

\subsubsection{Clinch River (1992)}

This survey was conducted as part of the 1992 ORR survey, described earlier, and covered the Clinch River from Melton Hill Dam to the city of Kingston, a straight-line distance of approximately 13.5 miles. The survey consisted of a single pass over each bank of the river and its major tributaries. The purpose of the Clinch River survey was to obtain radiation measurements over the exposed river banks before the scheduled late-April water level increase by the Tennessee Valley Authority. Three anomalous regions of interest (ROIs) that were found by the Clinch River survey were previously detected by the 1992 ORR survey [at White Oak Floodplain (ORNL) and at Campbell's Bend (K-25)]. The Clinch River survey also detected five additional ROIs:

ROI 36-Near Grassy Creek Tributary on Bear Creek Road (attributed to a low-level wasteprocessing, compaction, and incineration facility), cesium-137 and cobalt-60.

ROI 37-At the confluence of Grassy Creek Tributary and Clinch River, cesium-137.

ROIs 38-40-Near Clinch River, upstream of, near, and downstream of Campbell's Bend, cesium137 , relatively low levels.

\subsubsection{Portsmouth Gaseous Diffusion Plant (1993)}

An aerial radiological survey was conducted from August 10-16, 1993, over the 78 squarekilometer area of the Portsmouth plant and surrounding area near Portsmouth, Ohio. This survey was conducted at an altitude of 150 feet using a helicopter bearing two large detector pods and a REDAR IV. A GPS differential navigation system allowed georeferencing of recorded data. Ground- 
based soil sample and pressurized ion chamber measurements were collected at four locations for validation of aerial data.

Both gross count analysis (counts in the spectrum between 38 and 3,026 keV) and man-made count extraction were performed. Contours of the terrestrial gamma exposure rate extrapolated to 1 meter AGL were generated on a spatial basis. Terrestrial gamma exposure rates varied from roughly 7 to 14 microroentgens per hour at 1 meter above ground. Analysis of man-made sources and for the U-238 decay product protactinium-234m revealed elevated protactinium readings at six sites within the plant boundary. At a seventh site, only U-235 was observed. No other sources of gamma-emitting material were detected either on- or off-site. The only major differences from the 1990 survey data were the presence of a truck carrying radioactive materials in the 1990 survey and the existence of two additional sites (a conveyor and loading dock area) noted in 1993 data. See Fig. 9 for contours of manmade radiation count at PORTS. 


\section{DATA PROCESSING AND QUALITY ASSURANCE (GIS AND COMPUTER MODELING, CPED)}

\subsection{PROCESSED DATA DELIVERED BY CONTRACTOR (EG\&G/EM)}

The aerial gamma radiological data are received from EG\&G/EM in the form of contour or point data that has been processed from the raw data recorded by the sensors. Data transformation is required by GIS and Computer Modeling (GCM) to convert the data to Arc/Info coverages and to make necessary conversions to geographic coordinate systems used by ER. Quality assurance measures are applied to the data to ensure its spatial validity and to assess its usefulness to the ER Program.

\subsubsection{Paducah Gaseous Diffusion Plant (1990)}

The Remote Sensing Program received a copy of the 1990 survey from the contractor (EG\&G/EM) shipped October 28, 1994. Arc/Info coverages for both gross and man-made gamma counts were delivered in Arc/Info export format depicting both contours and polygons with coordinates in decimal degrees (latitude and longitude).

\subsubsection{Portsmouth Gaseous Diffusion Plant (1990)}

The Remote Sensing Program received a copy of the 1990 survey from the contractor (EG\&G/EM) shipped October 28, 1994. Arc/Info coverages for both gross and man-made gamma counts were delivered in Arc/Info export format depicting both contours and polygons with coordinates in decimal degrees (latitude and longitude).

\subsubsection{Oak Ridge Reservation (1992)}

These data for the ORR were shipped by EG\&G/EM on August 31, 1992, in Arc/Info export format (Administrative Grid coordinate system), processed by the GCM group, and installed subsequently in the Oak Ridge Environmental Information System (OREIS).

\subsubsection{Clinch River (1992)}

The data were originally shipped by EG\&G/EM June 10, 1993. Formatting problems with the Clinch River dataset were finally corrected by EG\&G/EM in November 1994 . They forwarded the corrected dataset to GCM at that time. Data were delivered as an Arc/Info point coverage with manmade radiological values for each point in the UTM (Zone 16) coordinate system, formatted as an Arc/Info export file.

\subsubsection{Portsmouth Gaseous Diffusion Plant (1993)}

The data from the 1993 survey were shipped July 7, 1994, by EG\&G/EM and received in Oak Ridge by the Remote Sensing Program July 22, 1994. Data were received as uncompressed Arc/Info export files (one each for gross count and man-made gamma) as line coverages with radiological values for each arc. Data were delivered in the Universal Transverse Mercator (UTM) (Zone 17) coordinate system. 


\subsection{SUMMARY OF DATA TRANSFORMATION AND ANALYSIS PROCEDURES}

The following steps were used to transform and analyze the data:

1. Initially, the 1990 Paducah and Portsmouth and 1993 Portsmouth data were extracted from several floppy disks. The Arc/Info .e00 files were imported into the system using the IMPORT command. The DESCRIBE command was then used to identify that the 1990 data were in geographic (latitude/longitude) coordinates. The 1993 Portsmouth data were in UTM coordinates. The PROJECT command was used to bring the data for Portsmouth into the Ohio South (Zone 5001) State Plane Coordinate System in meters, and the data for Paducah into the Kentucky South (Zone 4001) State Plane Coordinate System in meters, both in North American Datum (NAD) NAD83.

This data importation and projection was performed for both the man-made and the gross count data for both the Portsmouth and Paducah sites.

2. Digital mapping of the two facilities was previously performed. Arc/Info Arc Macro Language script programs from that effort were modified to generate spotting maps for the gamma data, and appropriate cartographic symbology was developed for both the man-made and gross count data. Classification was performed, and appropriate legends were developed for the data. In the Arc Attribute Tables (.aat), a SYMBOL attribute was added to the table for each element. This was used in conjunction with the COLOR.LIN line set to generate the spotting maps used for data validation.

3. Man-made and gross count plots integrated with the TIGER vector data were compared to aerial photographs for correspondence with plant and surface features at Portsmouth and Paducah, such as buildings and other facilities. The plots were also compared to published reports of the surveys by EG\&G/EM for spatial agreement of gamma anomalies.

4. The data for the 1992 Clinch River survey were different from the data for Portsmouth and Paducah sites, inasmuch as the data were derived from an overflight of the area and sent to the Remote Sensing Program in a point format, rather than an arc format. The data were stated by EG\&G/EM to be in the UTM coordinate system (Zone 16). However, this proved difficult to confirm. As a result of consistent unsuccessful attempts to use standard projection commands, a non-standard PROJECTION command was used in which the X-SHIFT and Y-SHIFT parameters were used to align the data into the Tennessee State Plane Coordinate System in meters for NAD83.

5. Road network and hydrologic vector data from the U.S. Census TIGER files were used as a basemap, as the Clinch River gamma flyover data were captured over a wide area to the west of the ORR, and standard basemaps did not encompass the imaged area. The imaged area ranged from Kingston in the west to the ORNL plant in the east, K-25 in the north, and Interstate 40 in the south, upstream as far as Melton Lake Dam. These TIGER data were PROJECTED into Tennessee State Plane (NAD83) for alignment with the overflight data and were subset into a rectangular box encompassing the flyover area. A classification of the data was performed so that a legend could be generated, and, in the Point Attribute Table [.pat], the SYMBOL attribute was added for each element. An appropriate value was given to each element in conjunction with the COLOR.MRK marker set. 
6. Available LANDSAT Thematic Mapper data was both subset and geo-referenced to align with both the TIGER basemap data and the flyover sampling points. Initial plots of bands 7, 4, 1 [RGB] of the LANDSAT raster cells, along with vector overlays of the TIGER basemap and flyover point data, generated a map which was far too visually cluttered. Consequently, a final check map used bands 1,2 , and 3 of the satellite data, which depicts land features, the TIGER vectors, and overflight point gamma data (Fig. 8). The check plot was reviewed for spatial agreement of Clinch River flight line point data with Clinch River and its major tributaries. The data were also compared to the 1992 ORR gamma contours for consistency in location of gamma anomalies. 


\section{DESCRIPTIONS OF GROSS COUNT AND MAN-MADE GAMMA DATASETS}

Seven additional Arc/Info gamma coverages are available for Paducah, Portsmouth, and Oak Ridge as a result of data received by the ER Remote Sensing Program from EG\&G in calendar year 1994. The additional processing, as described above, created the final Arc/Info coverages. These seven new coverages supplement coverages of the ORR, both man-made and gross count gamma, from the 1992 radiological survey, already submitted to OREIS.

The new gamma "coverages" are provided in the appropriate. State Plane (NAD83) coordinate system.

1. pad90gc-Paducah 1990 gross count gamma, an Arc/Info line coverage, Kentucky South State Plane (NAD83), Zone 4001.

2. pad90mm-Paducah 1990 man-made gamma, an Arc/Info line coverage, Kentucky South State Plane (NAD83), Zone 4001.

3. port90gc-Portsmouth 1990 man-made gamma, an Arc/Info line coverage, Ohio South State Plane (NAD83) coordinates, Zone 5001.

4. port90mm-Portsmouth 1990 gross count gamma, an Arc/Info line coverage, Ohio South State Plane (NAD83) coordinates, Zone 5001.

5. port93gc-Portsmouth 1993 man-made gamma, an Arc/Info line coverage, Ohio South State Plane (NAD83) coordinates, Zone 5001.

6. port $93 \mathrm{~mm}$-Portsmouth 1993 gross count gamma, an Arc/Info line coverage, Ohio South State Plane (NAD83) coordinates, Zone 5001.

7. clinch92mm-Oak Ridge Clinch River 1992 man-made gamma only, an Arc/Info point coverage, Tennessee State Plane (NAD83) coordinates, Zone 5301. 


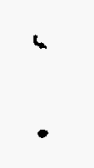




\section{REFERENCES}

Chemrad Tennessee Corp. May 5, 1994. Final Report on USRADS Surveys at the Oak Ridge National Laboratory SWSA-4 (Conducted December 14, 1993 through March 4, 1994). Oak Ridge, Tenn.

Christel, L. M. June 10, 1993. Clinch River media transmittal letter to J. F. Hines. No. SIGIS-94-102.

Christel, L. M. July 7, 1994. 1993 Portsmouth Arc radiation contours media transmittal letter to J. F. Hines. No. SIGIS-94-118.

Guss, P. P. September, 1992. An Aerial Radiological Survey of the Portsmouth Gaseous Diffusion Plant and Surrounding Area, Portsmouth, Ohio (Date of Survey: July, 1990). Report No. EGG 10617-1154. EG\&G Energy Measurements, Las Vegas, Nev.

Hoover, R. A. February, 1994. An In Situ Survey of the Paducah Gaseous Diffusion Plant and Surrounding Area, Paducah, Kentucky (Date of Survey: May, 1990); Report No. EGG 11265. 1010, EG\&G Energy Measurements, Las Vegas, Nev.

King, A. D.; Doll, W. E.; Durfee, R. C.; Luxmoore, R. J.; Conder, S. R.; and Nyquist, J. E. December, 1993. Strategic Plan for the Utilization of Remote Sensing Technologies in the Environmental Restoration Program. Report ES/ER/TM-97. Martin Marietta Energy Systems, Inc., Oak Ridge, Tenn.

Maurer, R. J. 1992. An Aerial Radiological Survey of the Paducah Gaseous Diffusion Plant and Surrounding Area, Paducah, Kentucky (Date of Survey: April, 1992). Report No. EGG 10617-1107. EG\&G Energy Measurements, Las Vegas, Nev.

Maurer, R. J. August, 1992. An Aerial Radiological Survey of the Oak Ridge Reservation, Oak Ridge, Tennessee; Report No. EGG 10617-1229. EG\&G Energy Measurements, Las Vegas, Nev.

Pickus, J. October 28, 1994. 1990 Portsmouth / Paducah radiation survey data (Arc/Info) media transmittal letter to R. C. Durfee, No. SIGIS-94-182.

Sampoll-Ramirez, G. September, 1994. An Aerial Radiological Survey of the Portsmouth Gaseous Diffusion Plant and Surrounding Area, Piketon, Ohio (Date of Survey: August, 1993); Report No. EGG 11265-1085. EG\&G Energy Measurements, Las Vegas, Nev. 


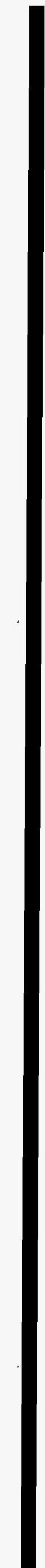


Appendix FIGURES 


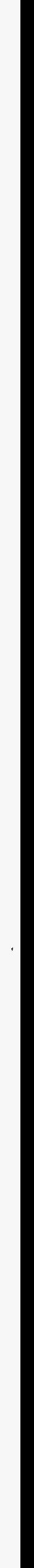




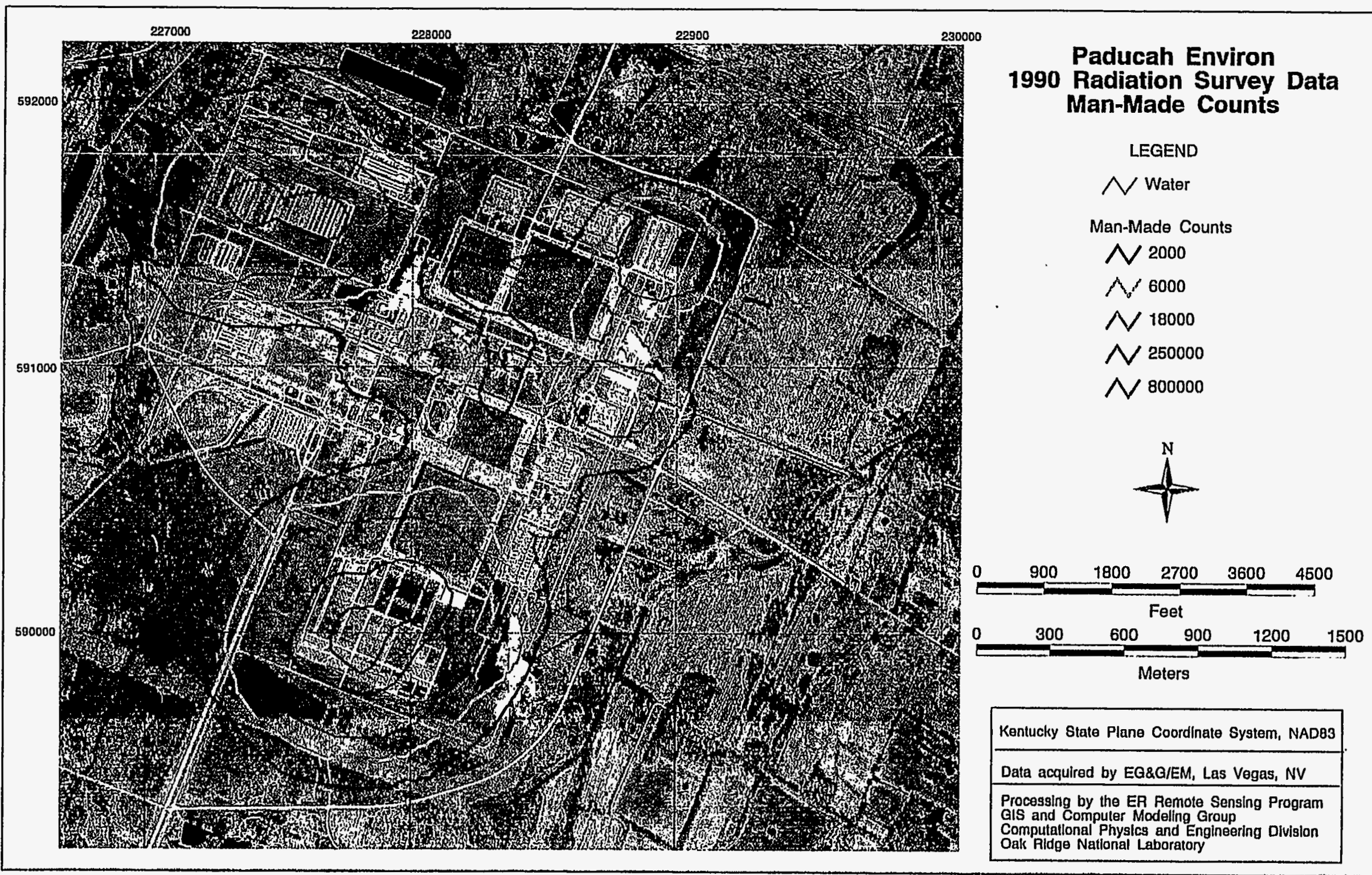

Fig. 1. Contours of man-made gamma radiation at Paducah Gascous Diffusion Plant. Data from a 1990 airborne radiological survey are overlaid on natural color photography from the ER Basemap Program. 


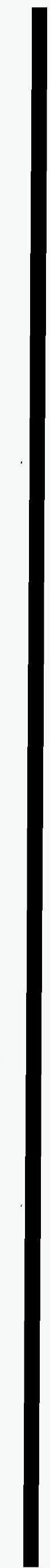




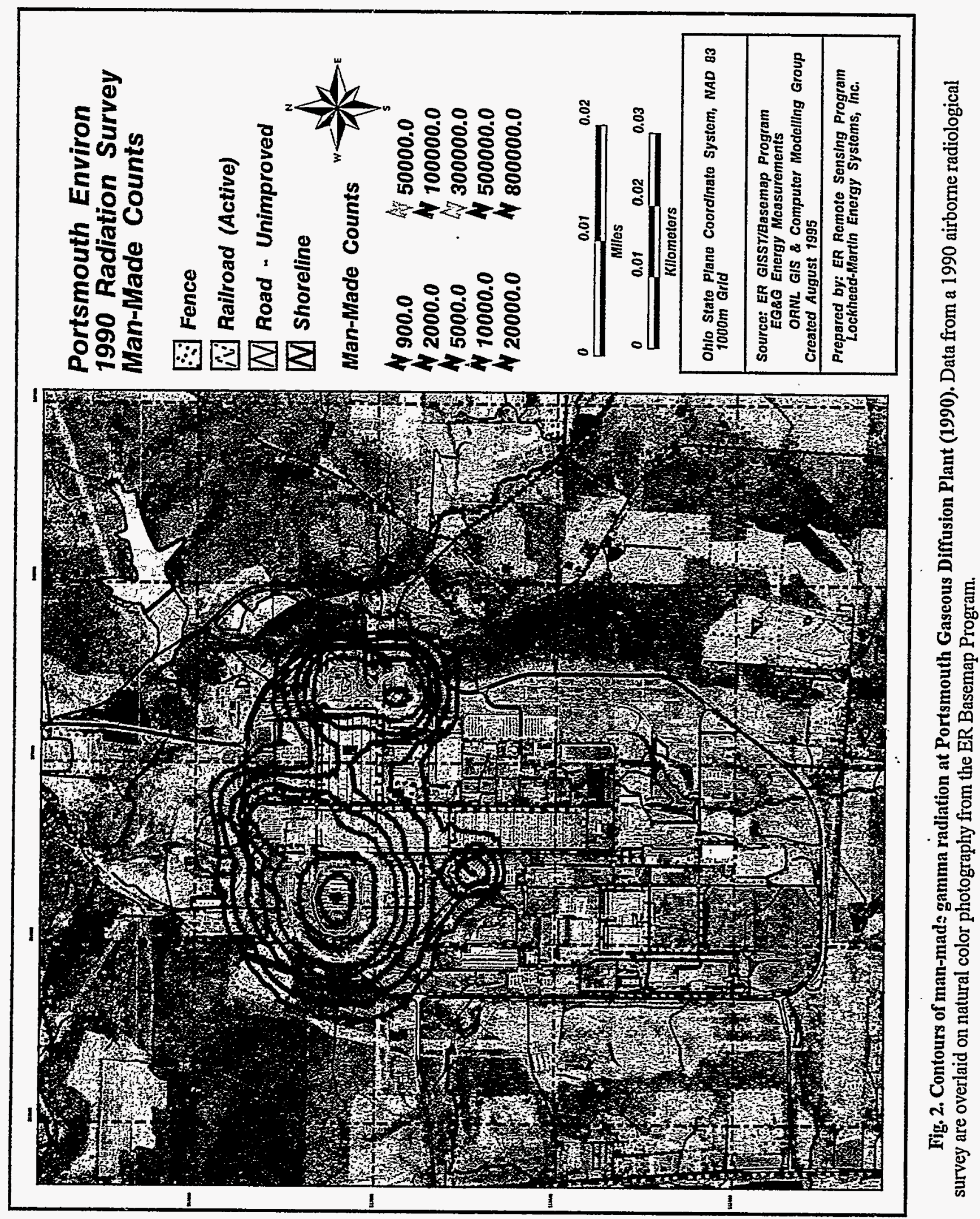




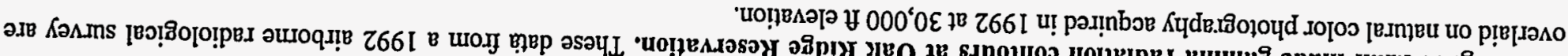

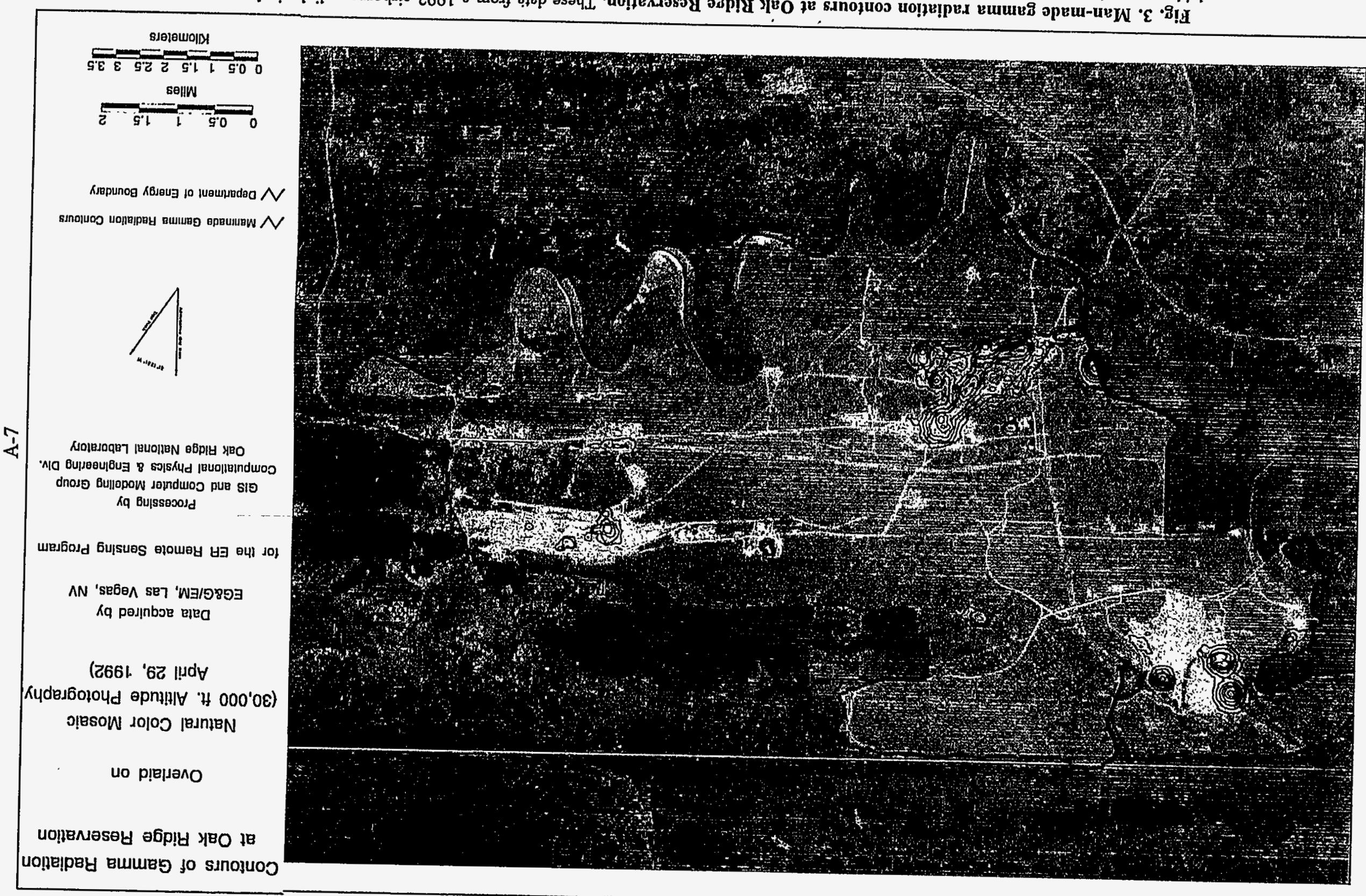





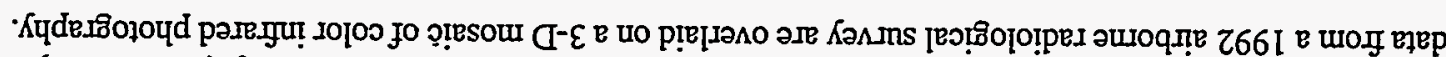

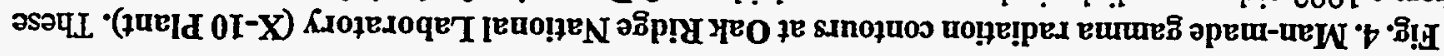

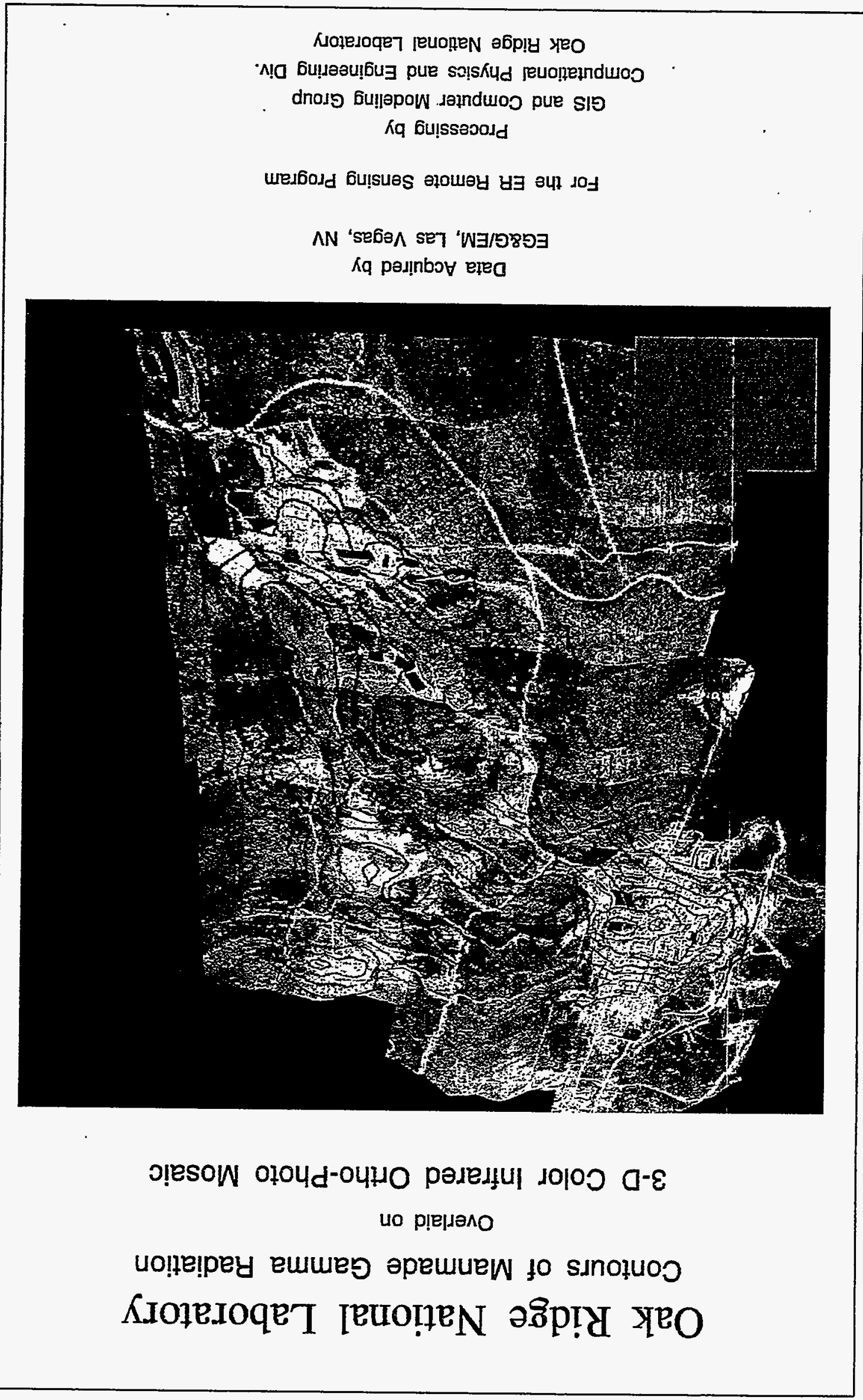



是

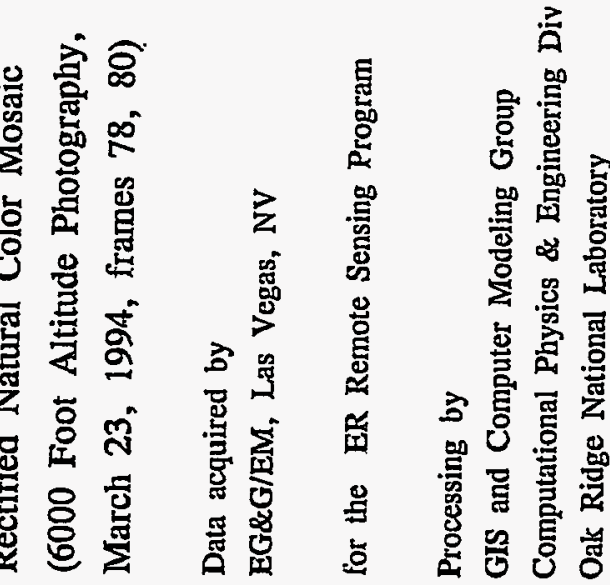

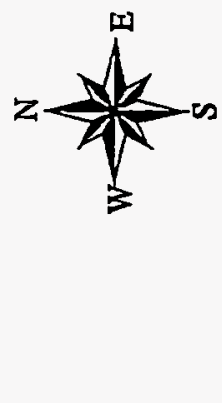

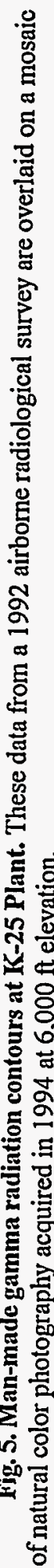

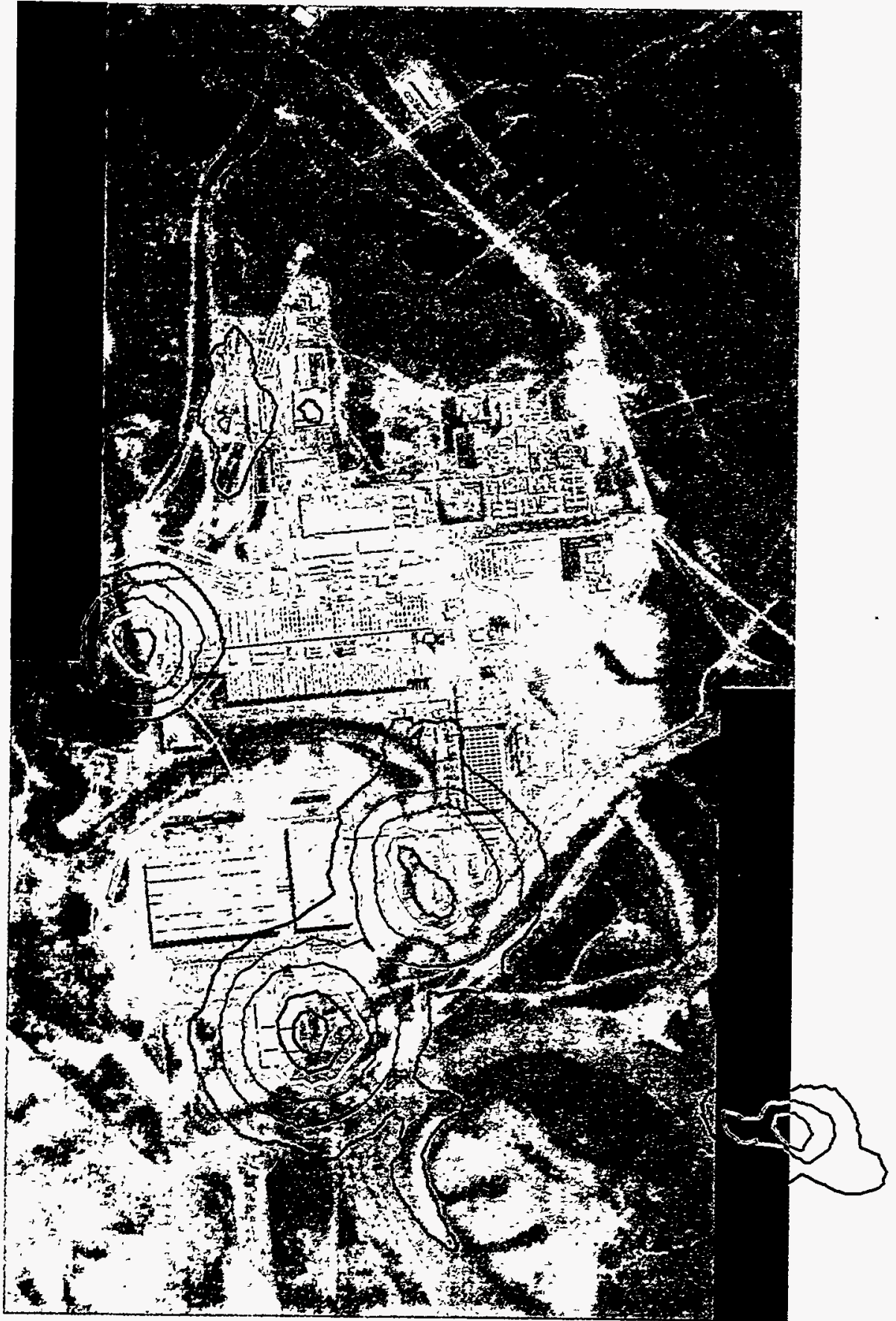

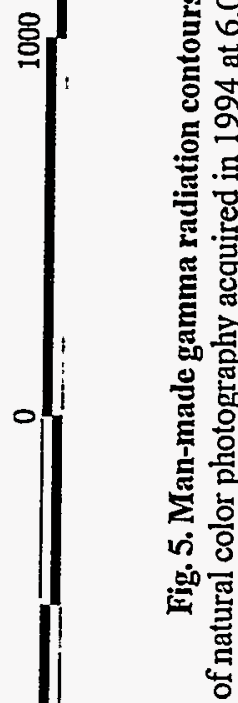




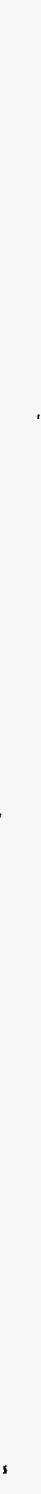




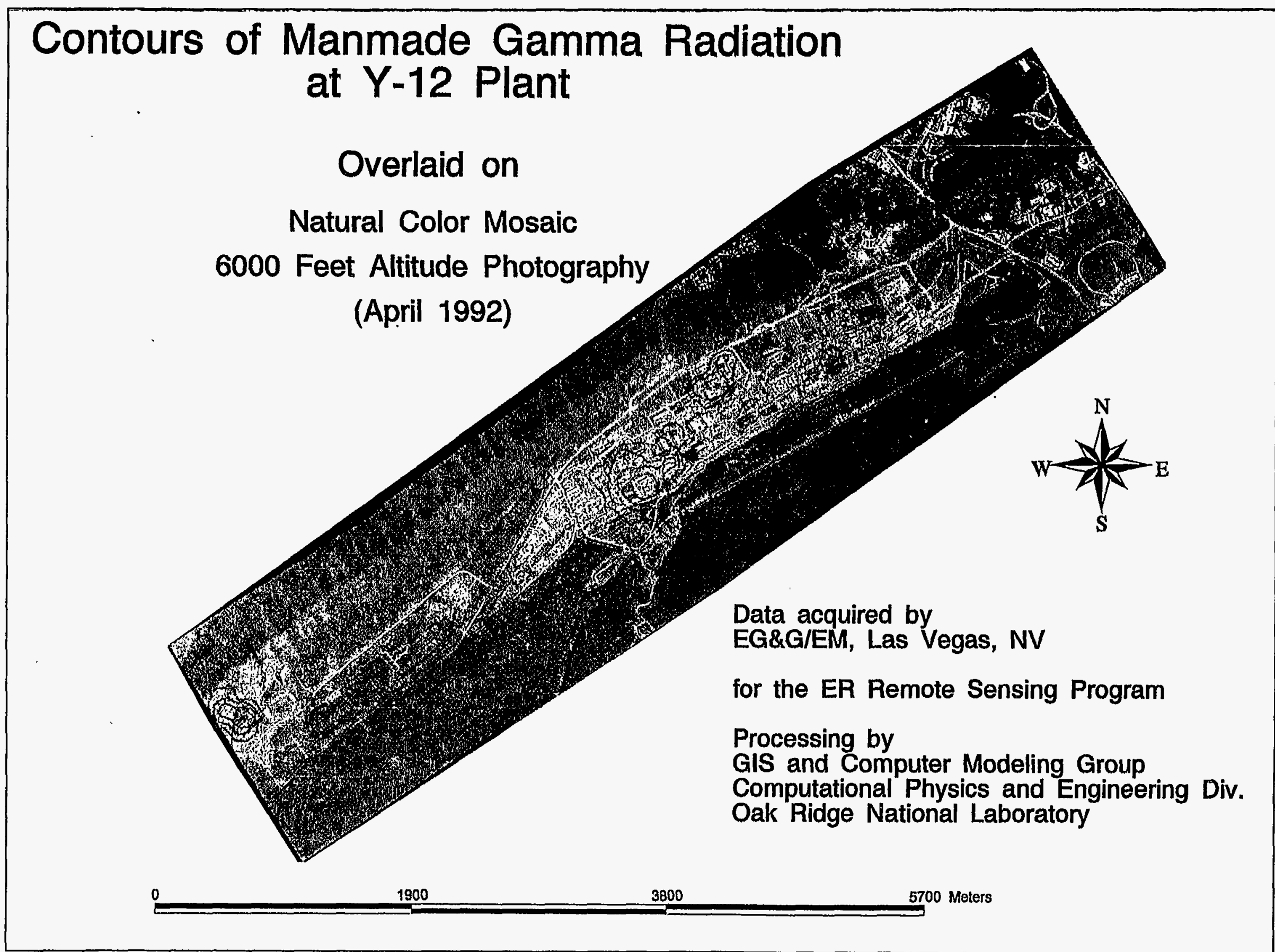

Fig. 6. Contours of man-made gamma radiation at Y-12 Plant. These data from a 1992 airborne radiological survey are overlaid on a mosaic of natural color photography acquired in April, 1992 at $6,000 \mathrm{ft}$ elevation. 



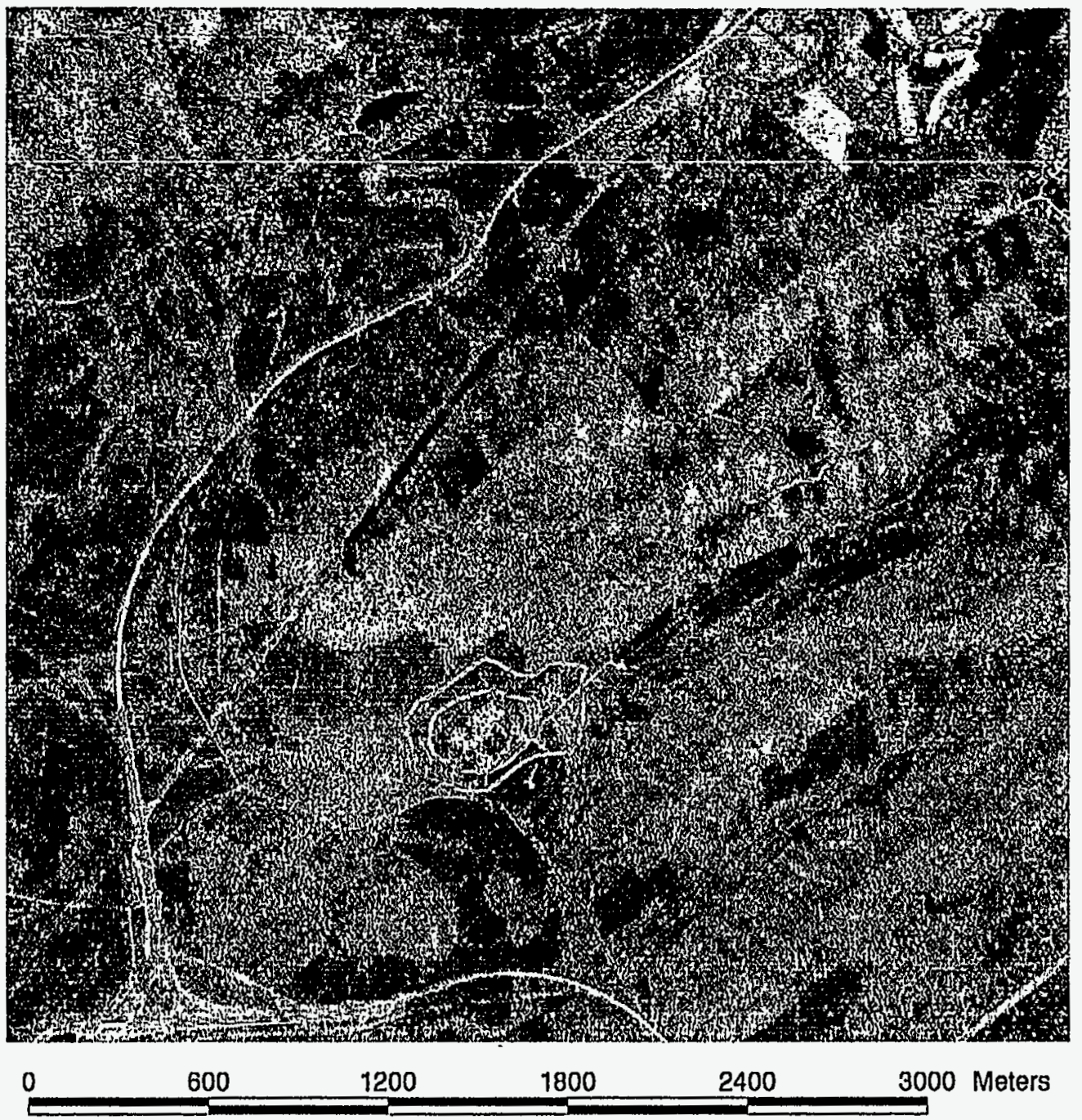

\section{Contours of Manmade Gamma Radiation Near East Fork Poplar Creek}

Overlaid on

Natural Color Mosaic

(7200 Feet Altitude Photography

- from ER Basemap Program, March 1993)

Gamma data acquired by EG\&G/EM, Las Vegas, NV

for the ER Remote Serising Program

Processing by

GIS and Computer Modeling Group Computational Physics \& Engineering Div. Oak Ridge National Laboratory

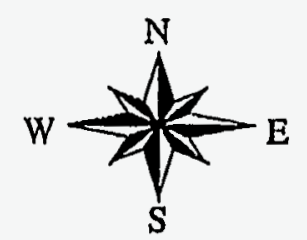

Fig.7. Contours of man-made gamma radiation near East Fork Poplar Creck. These data from a 1992 airborne radiological survey are overlaid on a mosaic of natural color pholography acquired in March, 1993, at 7,200 ft elevation for the ER Basemap Program. 
A- 17

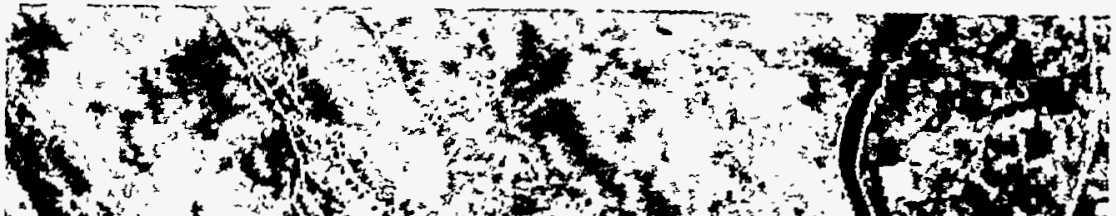

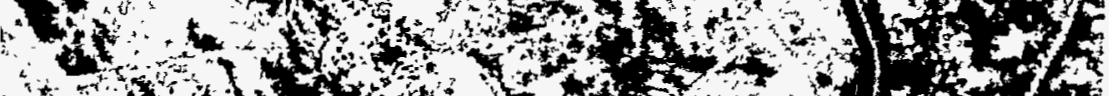

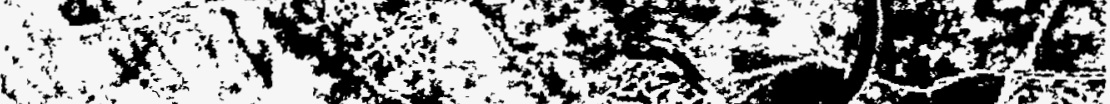

5 a

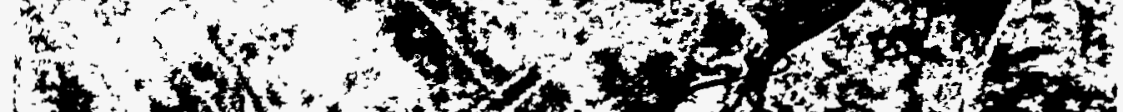

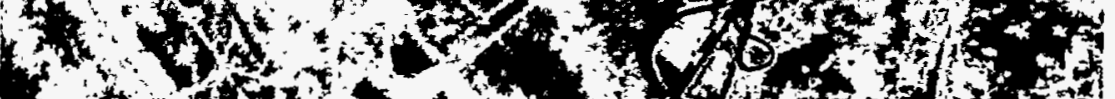

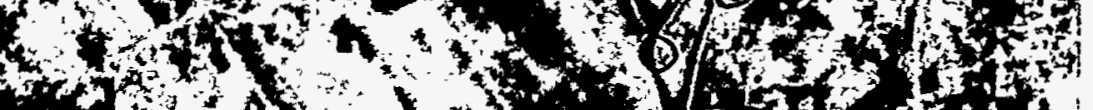

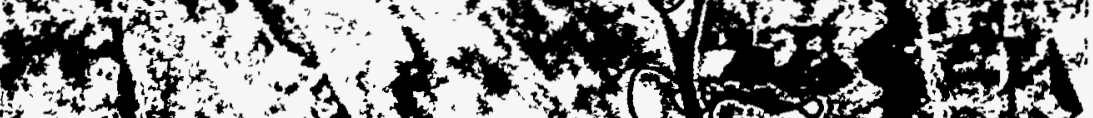

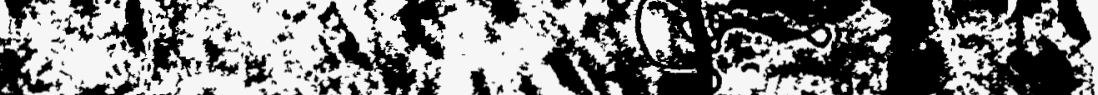

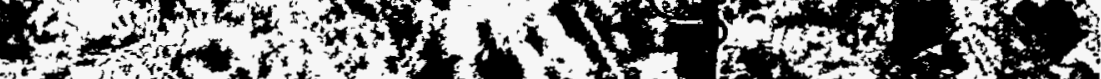
Cof

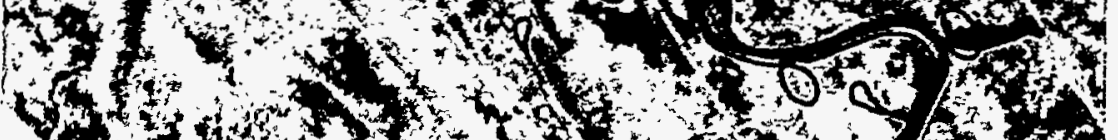

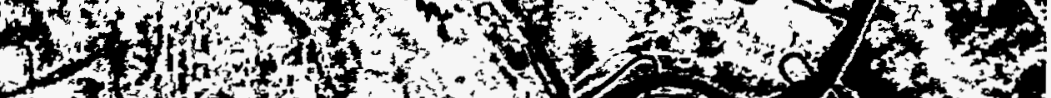

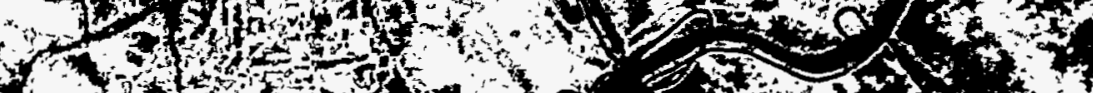

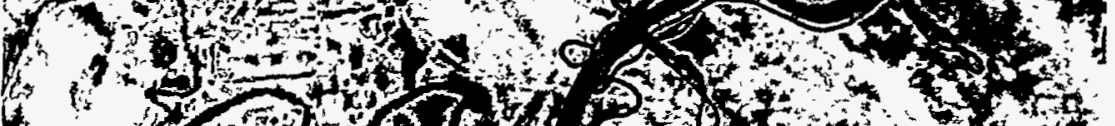

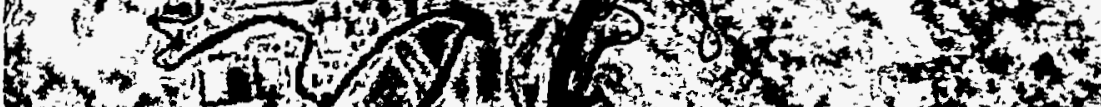

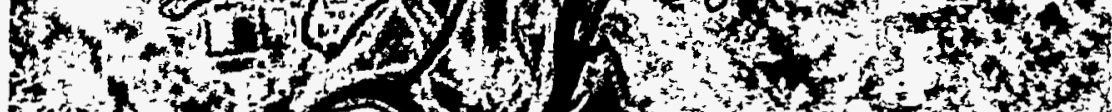

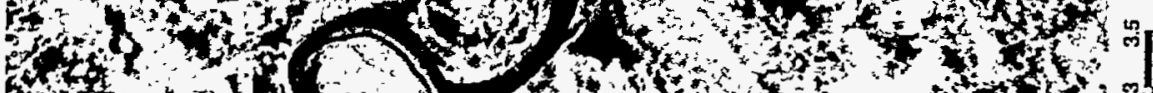

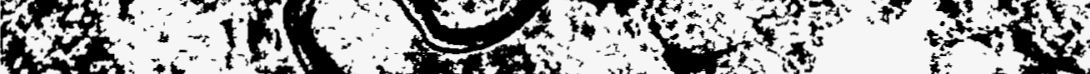

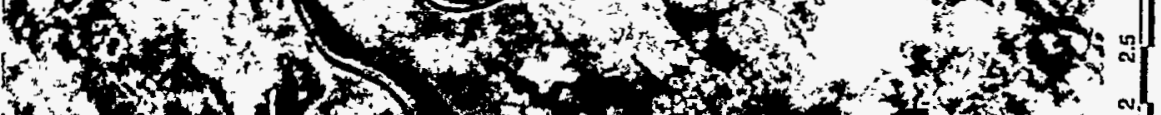

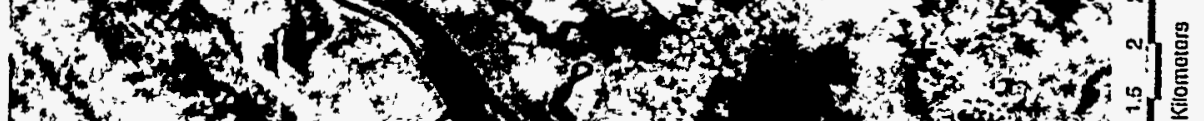

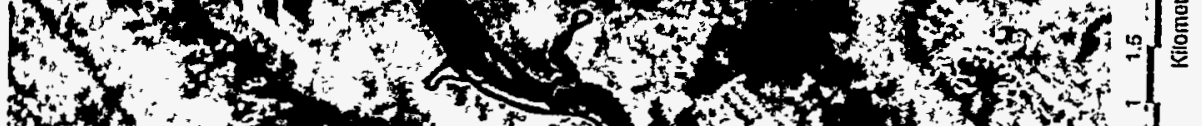

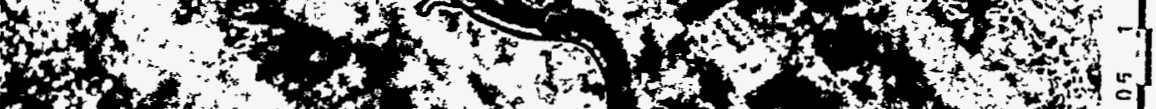

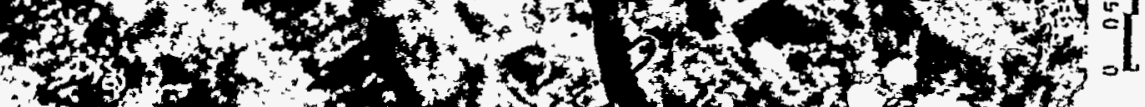

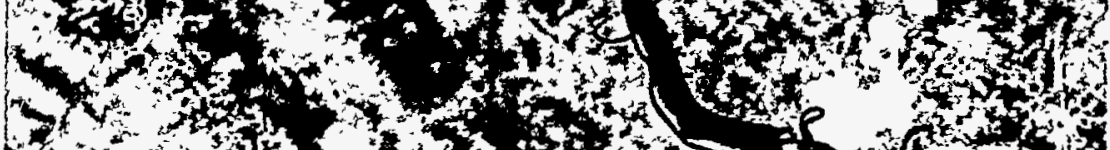

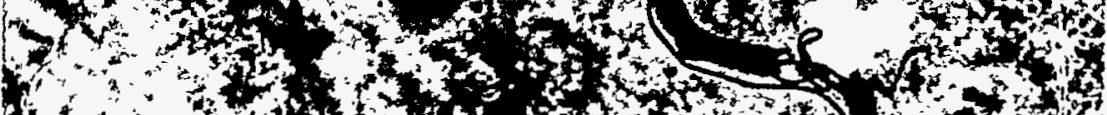

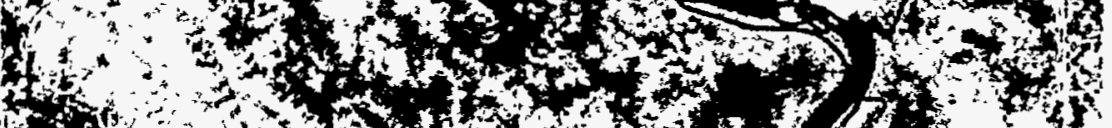
(5)

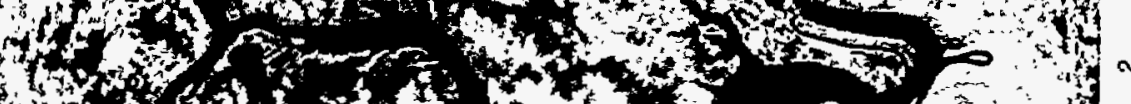

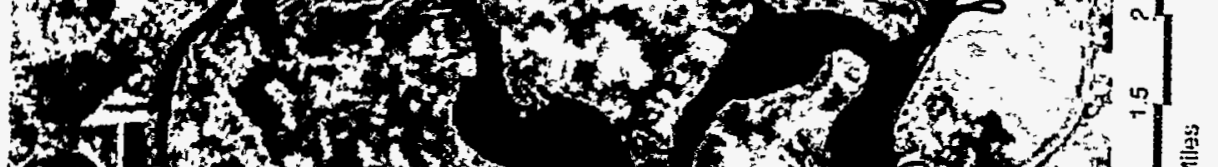
(1) (1)

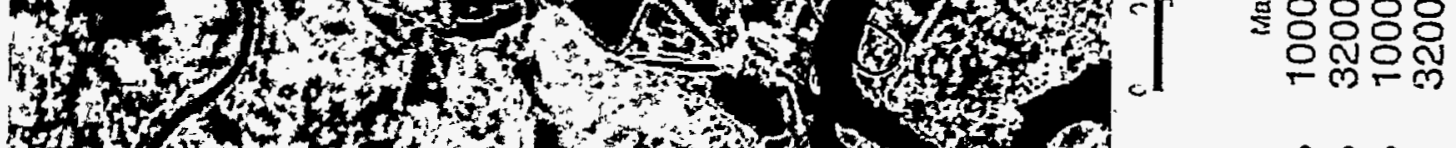

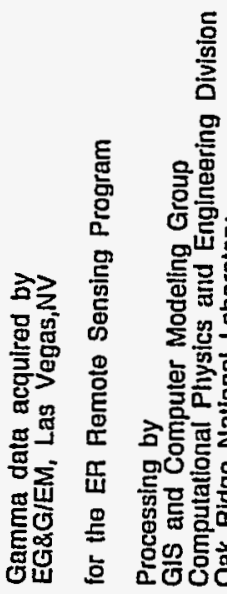

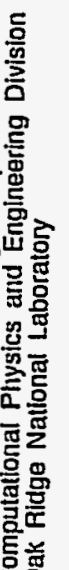





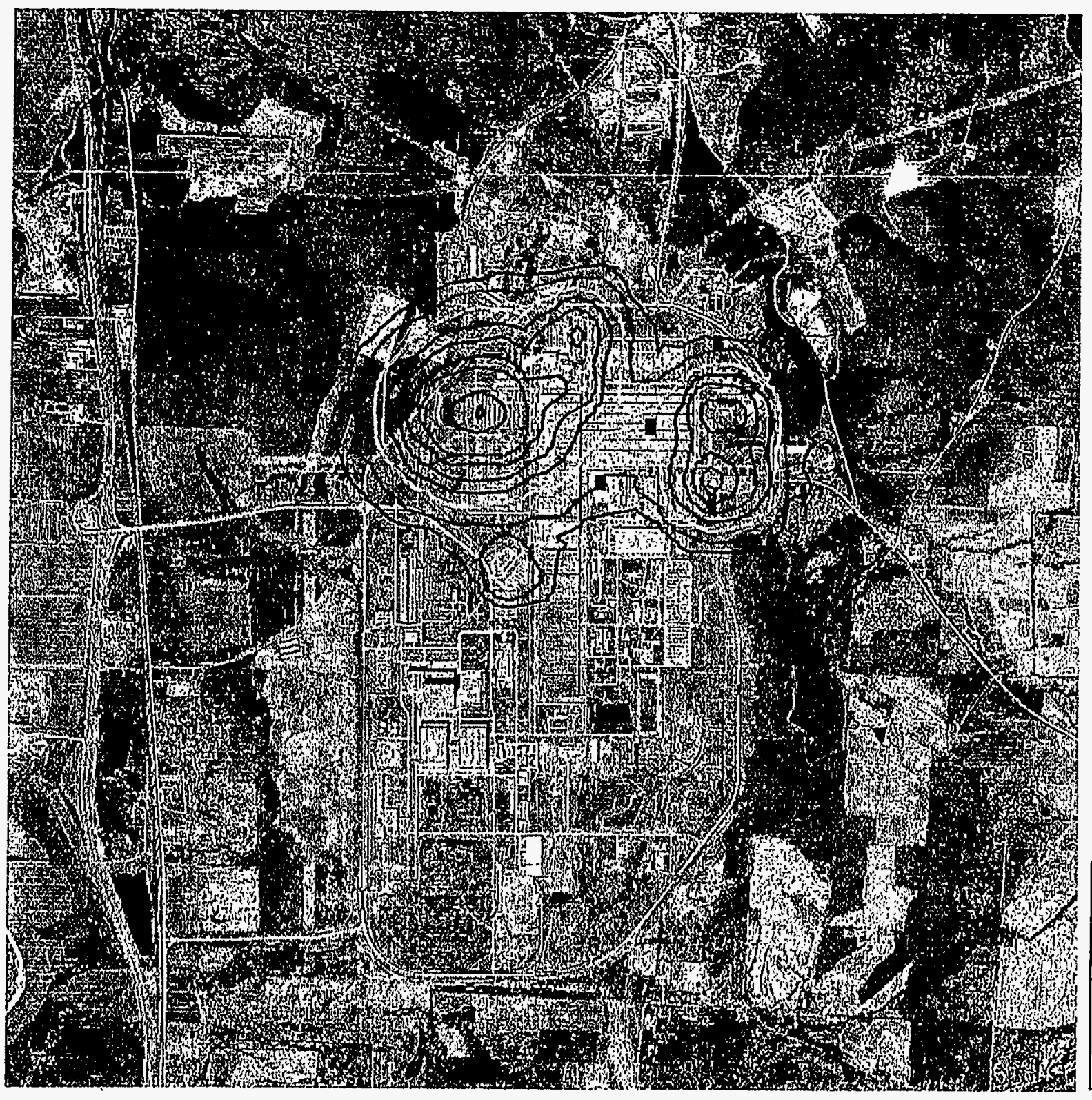

\section{Portsmouth Environ 1993 Radiation Survey Man-Made Counts}

Man-Made Counts

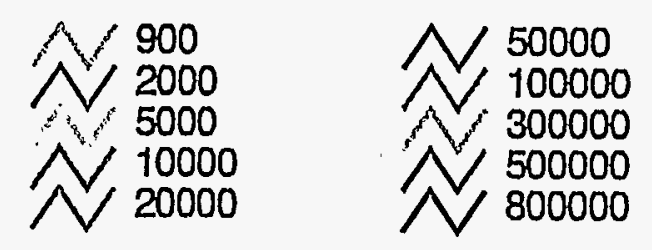

$+$

$\frac{3}{2}$

Ohio State Plane Coordinate System, NAD 83

Source: EG\&Q Energy Measurements

Propared by: ER Remote Sensing Program

GIS \& Computer Modeling Group

Computational Physics and Engineering Division Oak Hidge National Laboratory

Fig. 9. Contours of man-made gamma radiation at Portsmouth Gaseous Diffusion Plant (1993). Data from a 1993 airborne radiological survey are overlaid on natural color photography from the ER Basemap Program. 



\title{
DISTRIBUTION
}

\author{
1. L. V. Asplund \\ 2. H. L. Boston \\ 3. V. J. Brumback \\ 4. Y. Cheng \\ 5. J. S. Colley \\ 6. K. W. Cook \\ 7. R. B. Cook \\ 8. D. G. Cope \\ 9. W. E. Doll \\ 10-11. R. C. Durfee \\ 12. J. L. Gibson \\ 13. P. L. Goddard \\ 14. C. S. Haase \\ 15. P. A. Hamlett \\ 16. B. W. Henderson \\ 17. D. D. Herr \\ 18. R. K. Holmes \\ 19. B. L. Kimmel \\ 20-24. A. L. King \\ 25. J. R. Lyons \\ 26. J. C. Massey \\ 27. D. M. Matteo \\ 28. M. E. Musolf \\ 29. P. T. Owen \\ 30. P. J. Pace \\ 31. D. H. Pike \\ 32. A. S. Quist \\ 33. C. T. Rightmire \\ 34-35. J. L. Smyre \\ 36. T. D. Taylor \\ 37. D. C. White \\ 38. Central Research Library \\ 39. ER Document Management Center-RC \\ 40. S. P. Riddle, DOE Oak Ridge Operations Office, P.O. Box 2001, Oak Ridge, TN \\ 37831-8541 \\ 41. M. E. Hodgson, Department of Geography, University of South Carolina, Columbia, SC \\ 29208
}

